\title{
Front Matter: Volume 9993
}

, "Front Matter: Volume 9993," Proc. SPIE 9993, Millimetre Wave and Terahertz Sensors and Technology IX, 999301 (14 December 2016); doi: $10.1117 / 12.2264118$

SPIE. Event: SPIE Security + Defence, 2016, Edinburgh, United Kingdom 


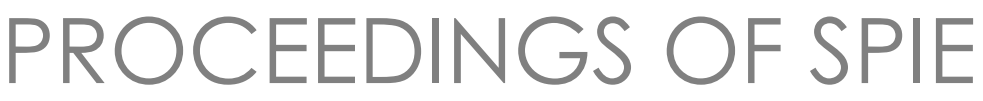

\title{
Millimetre Wave and Terahertz Sensors and Technology IX
}

\author{
Neil A. Salmon \\ Sherif Sayed Ahmed \\ Editors
}

28-29 September 2016

Edinburgh, United Kingdom

Sponsored by

SPIE

Cooperating Organisations

Innovation Centre for Sensor and Imaging Systems (United Kingdom)

ADS Scotland (United Kingdom)

The Knowledge Transfer Network (United Kingdom)

Visit Scotland (United Kingdom)

European Regional Development Fund (Belgium)

Technology Scotland (United Kingdom)

Published by

SPIE

Volume 9993

Proceedings of SPIE 0277-786X, V. 9993

SPIE is an international society advancing an interdisciplinary approach to the science and application of light.

Millimetre Wave and Terahertz Sensors and Technology IX, edited by Neil A. Salmon, Sherif Sayed Ahmed, Proc. of SPIE Vol. 9993, 999301 · (c) 2016 SPIE

CCC code: $0277-786 X / 16 / \$ 18 \cdot$ doi: $10.1117 / 12.2264118$

Proc. of SPIE Vol. $9993999301-1$ 
The papers in this volume were part of the technical conference cited on the cover and title page. Papers were selected and subject to review by the editors and conference program committee. Some conference presentations may not be available for publication. Additional papers and presentation recordings may be available online in the SPIE Digital Library at SPIEDigitallibrary.org.

The papers reflect the work and thoughts of the authors and are published herein as submitted. The publisher is not responsible for the validity of the information or for any outcomes resulting from reliance thereon.

Please use the following format to cite material from these proceedings:

Author(s), "Title of Paper," in Millimetre Wave and Terahertz Sensors and Technology IX, edited by Neil A. Salmon, Sherif S. Ahmed, Proceedings of SPIE Vol. 9993 (SPIE, Bellingham, WA, 2016) Six-digit Article CID Number.

ISSN: 0277-786X

ISSN:1996-756X (electronic)

ISBN: 9781510603905

ISBN: 9781510603912 (electronic)

Published by

SPIE

P.O. Box 10, Bellingham, Washington 98227-0010 USA

Telephone +1 3606763290 (Pacific Time) · Fax +1 3606471445

SPIE.org

Copyright (C) 2016, Society of Photo-Optical Instrumentation Engineers.

Copying of material in this book for internal or personal use, or for the internal or personal use of specific clients, beyond the fair use provisions granted by the U.S. Copyright Law is authorized by SPIE subject to payment of copying fees. The Transactional Reporting Service base fee for this volume is $\$ 18.00$ per article (or portion thereof), which should be paid directly to the Copyright Clearance Center (CCC), 222 Rosewood Drive, Danvers, MA 01923. Payment may also be made electronically through CCC Online at copyright.com. Other copying for republication, resale, advertising or promotion, or any form of systematic or multiple reproduction of any material in this book is prohibited except with permission in writing from the publisher. The CCC fee code is 0277-786X/16/\$18.00.

Printed in the United States of America.

Publication of record for individual papers is online in the SPIE Digital Library.

\section{SPIE. DIGITALY \\ SPIEDigitallibrary.org}

Paper Numbering: Proceedings of SPIE follow an e-First publication model. A unique citation identifier (CID) number is assigned to each article at the time of publication. Utilization of CIDs allows articles to be fully citable as soon as they are published online, and connects the same identifier to all online and print versions of the publication. SPIE uses a six-digit CID article numbering system structured as follows:

- $\quad$ The first four digits correspond to the SPIE volume number.

- The last two digits indicate publication order within the volume using a Base 36 numbering system employing both numerals and letters. These two-number sets start with $00,01,02,03,04,05,06,07,08,09,0 A, 0 B \ldots$. OZ, followed by 10-1Z, 20-2Z, etc. The CID Number appears on each page of the manuscript. 


\title{
Contents
}

\author{
$\checkmark$ Authors \\ vii Conference Committee
}

\section{PHENOMENOLOGY, SIGNATURES AND MODELLING I}

999302 Submillimetre wave imaging and security: imaging performance and prediction (Invited Paper) [9993-1]

999303 Through-the-wall UWB pulse radar for micro-motion detection [9993-2]

999305 New algorithm for detection of dangerous objects hidden on a human body using passive THz camera [9993-4]

\section{SYSTEMS AND CONCEPTS}

999306 Walk through screening with multistatic mmW technology (Invited Paper) [9993-5]

999307 A portable W-band radar system for enhancement of infrared vision in fire fighting operations [9993-6]

999308 Detection of MAVs (Micro Aerial Vehicles) based on millimeter wave radar [9993-7]

999309 Up-conversion of MMW radiation to visual band using glow discharge detector and silicon detector [9993-8]

9993 OA Millimeter-wave/THz FMCW radar techniques for sensing applications [9993-9]

9993 OB Experimental results and simulations from aperture synthesis three-dimensional radiometric imaging [9993-10]

\section{PHENOMENOLOGY, SIGNATURES AND MODELLING II}

9993 OC Molecular detection with terahertz waves based on absorption-induced transparency metamaterials (Invited Paper) [9993-1 1]

9993 OD Plasma shock waves excited by THz radiation [9993-12]

9993 OF A methodology for the optimisation of a mm-wave scanner [9993-14] 
PHENOMENOLOGY, SIGNATURES AND MODELLING III

9993 OG Passive microwave remote discriminator for the marine applications [9993-15]

DEVICES AND ENABLING TECHNOLOGY

9993 이 Terahertz waveguides based on multichannel sapphire shaped crystals [9993-17]

POSTER SESSION

9993 OK Polarization ratio property and material classification method in passive millimeter wave polarimetric imaging [9993-18]

9993 OL A hardware-efficient DOA estimation method based on digital channelization receiver [9993-19]

9993 OM Electromagnetic model based SAR ATR through attributed scatterers [9993-20] 


\title{
Authors
}

Numbers in the index correspond to the last two digits of the six-digit citation identifier (CID) article numbering system used in Proceedings of SPIE. The first four digits reflect the volume number. Base 36 numbering is employed for the last two digits and indicates the order of articles within the volume. Numbers start with 00, 01, 02, 03, 04, 05, 06, 07, 08, 09, 0A, 0B...0Z, followed by 10-1Z, 20-2Z, etc.

\author{
Abramovich, Amir, 09 \\ Aharon Akram, Avihai, 09 \\ Ahmed, Sherif Sayed, 06 \\ Ambacher, Oliver, 07 \\ Appleby, R., 02 \\ Caris, Michael, 08 \\ Chen, Zengping, OL \\ Cheng, Yayun, OK \\ Chernomyrdin, Nikita $\vee$., $0 \mathrm{l}$ \\ Denisov, Alexander, OG \\ Denisova, Kateryna, OG \\ Fan, Xiaolei, OL \\ Ferguson, S., 02 \\ G. Rodrigo, Sergio, OC \\ Gao, Feng, OM \\ Gaugue, Alain, 03 \\ Gui, Liangqi, OK \\ Gumbmann, Frank, 06 \\ Guo, Rui, OL \\ Hahmann, Konstantin, 07 \\ Higgins, Michael D., OA \\ Hommes, Alexander, 08 \\ $\mathrm{Hu}, \mathrm{Fei}, \mathrm{OK}$ \\ Huang, Xiaohong, OM \\ Hülsmann, Axel, 07 \\ Johannes, Winfried, 08 \\ Karasik, Valeriy E., Ol \\ Katyba, Gleb M., Ol \\ Kleiner, Bernhard, 07 \\ Klenner, Mathias, 07 \\ Kopeika, Natan S., 09 \\ Kuchik, Igor E., 05 \\ Kühn, Jutta, 07 \\ Kurlov, Vladimir N., Ol \\ Lin, Qianqiang, OL \\ Liv, Hao, OG \\ Liu, Siyuan, OK \\ Louis, Georges, 03 \\ $\mathrm{Ma}$, Conghui, $\mathrm{OM}$ \\ Martín-Moreno, L., OC \\ Ménard, Michel, 03 \\ Mérelle, Vincent, 03 \\ Mirando, D. Amal, OA \\ Mukhina, Elena E., Ol \\ Noetel, Denis, 08 \\ Peng, Xiaohui, OK \\ Petkie, Douglas T., OA \\ Peyton, Anthony J., OF \\ Podd, Frank J. W., OF
}

Qi, Bo, OK

Qiu, Jinghui, OG

Reshetov, Igor V., Ol

Rossolenko, Sergei N., Ol

Rozban, Daniel, 09

Rudin, S., OD

Rupper, G., OD

Salmon, Neil A., OB

Schlechtweg, Michael, 07

Shestakov, Ivan L., 05

Shikunova, Irina A., Ol

Shur, M., OD

Soldovieri, Francesco, OG

Stanko, Stephan, 08

Stec, L. Zoë, OF

Trofimov, Vladislav $\vee ., 05$

Trofimov, Vyacheslav A., 05

Ulrich, Michael, 07

Wang, Fenggui, OA

Wen, Gongjian, OM

Yang, Xiaoliang, $O M$

Yitzhaky, Yitzhak, 09

Yurchenko, Stanislav O., 01

Zaytsev, Kirill I., Ol

Zech, Christian, 07

Zhang, Yue, OL 


\title{
Conference Committee
}

\author{
Symposium Chairs
}

David H. Titterton, United Kingdom Defense Academy

(United Kingdom)

Symposium Co-chairs

Ric Schleijpen, TNO Defence, Security and Safety (Netherlands)

Karin Stein, Fraunhofer-Institut für Optronik, Systemtechnik und Bildauswertung (Germany)

Stuart S. Duncan, Leonardo-Finmeccanica (United Kingdom)

\section{Conference Chairs}

Neil A. Salmon, MMW Sensors Ltd. (United Kingdom)

Sherif Sayed Ahmed, Rohde \& Schwarz GmbH \& Co. KG (Germany)

Conference Program Committee

Amir Abramovich, Ariel University (Israel)

Hakan Altan, Middle East Technical University (Turkey)

Nicholas J. Bowring, Manchester Metropolitan University

(United Kingdom)

Stephan Dill, Deutsches Zentrum für Luft- und Raumfahrt e.V.

(Germany)

Charmaine Cisneros Franck, NASA Langley Research Center (United States)

Marcin Kowalski, Military University of Technology (Poland)

Wojciech Knap, Université Montpellier 2 (France)

Steven R. Murrill, U.S. Army Research Laboratory (United States)

Markus Peichl, Deutsches Zentrum für Luft- und Raumfahrt e.V. (Germany)

Douglas T. Petkie, Wright State University (United States)

Christopher A. Schuetz, Phase Sensitive Innovations, Inc.

(United States)

Vyacheslav A. Trofimov, Lomonosov Moscow State University (Russian Federation)

Vincent P. Wallace, The University of Western Australia (Australia) 
Session Chairs

1 Phenomenology, Signatures and Modelling I

Nicholas J. Bowring, Manchester Metropolitan University

(United Kingdom)

Sherif Sayed Ahmed, Rohde \& Schwarz GmbH \& Co. KG (Germany)

Wojciech Knap, Université Montpellier 2 (France)

Steven R. Murrill, U.S. Army Research Laboratory (United States)

2 Systems and Concepts

Neil A. Salmon, MMW Sensors Ltd. (United Kingdom)

Hakan Altan, Middle East Technical University (Turkey)

Christopher A. Schuetz, Phase Sensitive Innovations, Inc. (United States)

3 Phenomenology, Signatures and Modelling II

Douglas T. Petkie, Wright State University (United States)

Stephan Dill, Deutsches Zentrum für Luft- und Raumfahrt e.V. (Germany)

Neil A. Salmon, MMW Sensors Ltd. (United Kingdom)

$4 \quad$ Phenomenology, Signatures and Modelling III

Amir Abramovich, Ariel University (Israel)

Sherif Sayed Ahmed, Rohde \& Schwarz GmbH \& Co. KG (Germany)

Bacia Marcin, Wroclaw University of Science and Technology

(Poland)

5 Devices and Enabling Technology

Amir Abramovich, Ariel University (Israel)

Sherif Sayed Ahmed, Rohde \& Schwarz GmbH \& Co. KG (Germany)

Bacia Marcin, Wroclaw University of Science and Technology

(Poland) 